\title{
ENHANCEMENT OF THE OUTPUT POWER GENERATED FROM A HYBRID SOLAR THERMAL SYSTEM
}

\author{
Magdy M. Abdelhameed ${ }^{1}$, M. A. Abdelaziz ${ }^{2}$, A. Bayoumi ${ }^{3}$ \\ ${ }^{1}$ Head of department, Professor, ${ }^{2}$ Assistant Professor, Mechanical Engineering Department, Ain Shams University, Cairo, \\ Egypt \\ ${ }^{3}$ Teaching Assistant, Mechanical Engineering Department, The British University in Egypt, Cairo, Egypt
}

\begin{abstract}
This paper investigates the output power and increased the efficiency of a hybrid Photovoltaic/ Thermal (PV/T) modules through utilizing the heat generated from the surface of panels by one axial tracking of the hybrid PV/Tsystem by means of zenith angle and decreasing the heat generated from the PV modules by controlling the flow rate of the system. A comparison between theoretical and experimental work results for fixed and tracking PV/T hybrid system is presented. Comsol software package used to simulate the electromagnetic waves produced by the sun through solving Maxwell's equations in three dimensions and the sun irradiance is assumed to be Gaussian distribution across the twelve mourning hours. Beside that an experimental work is presented depending on the results conjured from the theoretical experience used in Comsol Multiphysics In the second part of the experimental work, one axial sun-tracking system is designed where the movement of a photo-voltaic module is controlled to follow the Sun's radiation using a Data acquisition card (DAQ) unit. Finally an active cooling system is designed and conducted to cool the fixed and tracking modules at which an absorber system consists of copper pipe welded with aluminium plate is attached underneath the PV modules to allow water flowing below the modules. In addition to the above an electrical analysis for both systems are presented where I-V, $P$ - $V$, power with 12 mourning hour's and electrical efficiency. Beside that the thermal analysis for the fixed and tracking PV modules and the piping water are presented where the input, output temperatures, the total energy of heat losses and thermal efficiency are calculated. As a result, a significant enhancement in the total electrical efficiency is observed with acceptable increase in the output water temperature.
\end{abstract}

Keywords: Cooling systems; DAQ; Hybrid; Comsol Multiphysics; Mat lab; Solid work; Lab view....

Table 1: Nomenclature

\begin{tabular}{|c|c|c|}
\hline Symbol & Description & Units \\
\hline$h$ & Planck's constant & $\begin{array}{c}6.626 * 10^{-34} \mathrm{~J} \\
* s\end{array}$ \\
\hline $\mathrm{C}$ & The speed of light & $3 * 10^{8} \mathrm{~m} / \mathrm{sec}$ \\
\hline$P_{12}$ & $\begin{array}{l}\text { The transition of an electron } \\
\text { from } E_{1} \text { to } E_{2}\end{array}$ & --------------' \\
\hline$g_{v}\left(E_{1}\right)$ & $\begin{array}{c}\text { The density of electrons in } \\
\text { the initial state }\end{array}$ & $m^{-3}$ \\
\hline$g_{c}\left(E_{2}\right)$ & $\begin{array}{c}\text { The density of available final } \\
\text { states }\end{array}$ & $m^{-3}$ \\
\hline $\mathrm{K}_{\mathrm{B}}$ & Boltzmann constant & $\begin{array}{l}1.38^{*} \\
10^{-23} \mathrm{~m}^{2 *} \\
\mathrm{~kg}^{2} \mathrm{~s}^{-2} * \\
\mathrm{~K}^{-1}\end{array}$ \\
\hline$q$ & The electron charge & $1.6^{*} 10^{-19} \mathrm{C}$ \\
\hline $\mathrm{T}$ & Temperature & $\mathrm{K}$ \\
\hline $\mathrm{E}_{\mathrm{p}}$ & The phonon energy & Joules \\
\hline $\mathrm{v}_{\mathrm{th}}$ & The thermal velocity & $10^{5} \mathrm{~m} / \mathrm{sec}$ \\
\hline $\mathrm{S}$ & The grid-shadowing factor & ----------- \\
\hline
\end{tabular}

\begin{tabular}{|c|c|c|}
\hline$r(\lambda)$ & The reflectance & --------- \\
\hline$\alpha(\lambda)$ & The absorption coefficient & $m^{-1}$ \\
\hline$\Gamma(\lambda)$ & The incident photon flux & -------- \\
\hline $\mathrm{I}$ & Current & $\mathrm{A}$ \\
\hline $\mathrm{V}$ & Voltage & $\mathrm{V}$ \\
\hline$I_{01}$ & Dark saturation Current & $\mathrm{A}$ \\
\hline$\eta_{\text {electric }}$ & PV efficiency. & $\%$ \\
\hline Pout & The maximum power output & $\mathrm{W}$ \\
\hline Pin & The total optical input power & $\mathrm{W}$ \\
\hline $\mathrm{V}_{\mathrm{oc}}$ & Open circuit voltage & $\mathrm{V}$ \\
\hline $\mathrm{FF}$ & Fill Factor. & $\%$ \\
\hline$\rho$ & Fluid Density & $\mathrm{Kg} / \mathrm{m}^{3}$ \\
\hline $\mathrm{T}$ & Time & $\mathrm{Sec}$ \\
\hline$u$ & Fluid velocity & $\mathrm{m} / \mathrm{sec}^{3}$ \\
\hline $\mathrm{P}$ & Electrical power out of PV & $\mathrm{W}$ \\
\hline$\mu$ & cell & $\mathrm{Pa} * \mathrm{~s}$ \\
\hline $\mathrm{Cp}$ & Heat capacity at constant & $\mathrm{J} / \mathrm{kg}^{*} \mathrm{~K}$ \\
& Tressure & $\mathrm{K} * m^{-1}$ \\
\hline$\nabla \mathrm{T}$ & Temperature Gradient & $\mathrm{W}$ \\
\hline$q_{l w}$ & Long wave energy & -------- \\
\hline $\mathrm{E}$ & Surface emissivity & \\
\hline & & \\
\hline
\end{tabular}




\begin{tabular}{|c|c|c|}
\hline$\Sigma$ & Stefan-Boltzmann constant & $\begin{array}{c}5.67 e^{-8} \\
\mathrm{~W} / m^{2} * K^{4}\end{array}$ \\
\hline $\mathrm{U}$ & $\begin{array}{c}\text { Overall heat transfer } \\
\text { coefficient }\end{array}$ & $\mathrm{W} / m^{2} * \mathrm{~K}$ \\
\hline A & $\begin{array}{c}\text { Plate surface area and PV } \\
\text { area }\end{array}$ & $m^{2}$ \\
\hline$t_{h}$ & Thickness of the plate & $\mathrm{M}$ \\
\hline A & Pipe surface area & $m^{2}$ \\
\hline$K_{S i}$ & Silicon thermal conductivity & $\mathrm{W} / \mathrm{m}^{2} * \mathrm{~K}$ \\
\hline$K_{A l}$ & $\begin{array}{c}\text { Aluminum thermal } \\
\text { conductivity }\end{array}$ & $\mathrm{W} / \mathrm{m}^{2} * \mathrm{~K}$ \\
\hline$K_{\text {Pipe }}$ & Pipe thermal conductivity & $\mathrm{W} / \mathrm{m}^{2} * \mathrm{~K}$ \\
\hline$h_{w}$ & Water thermal conductivity & $\mathrm{W} / \mathrm{m}^{2} * \mathrm{~K}$ \\
\hline$h_{\text {air }}$ & Air thermal conductivity & $\mathrm{W} / \mathrm{m}^{2} * \mathrm{~K}$ \\
\hline$r_{i n}$ & Pipe inner radius & $m$ \\
\hline$r_{\text {out }}$ & Pipe outer radius & $m$ \\
\hline $\mathrm{L}$ & Plate length & $m$ \\
\hline $\mathrm{W}$ & Plate width & $m$ \\
\hline $\mathrm{L}$ & Total pipe length & $m$ \\
\hline Q & The rate of heat transfer & $\mathrm{W}$ \\
\hline$\Delta \mathrm{T}$ & Temperature difference & $\mathrm{K}$ \\
\hline$Q_{\text {heat }}$ & Heat flux going into PV cell & $\mathrm{W} / \mathrm{m}^{2}$ \\
\hline $\mathrm{q}_{\mathrm{rad}}$ & Solar Irradiant & $\mathrm{W} / \mathrm{m}^{2}$ \\
\hline $\mathrm{V}_{\mathrm{mp}}$ & $\begin{array}{l}\text { Maximum power point } \\
\text { voltage }\end{array}$ & $\mathrm{V}$ \\
\hline $\mathrm{I}_{\mathrm{mp}}$ & $\begin{array}{c}\text { Maximum power point } \\
\text { current }\end{array}$ & A \\
\hline $\mathrm{E}_{\mathrm{in}}$ & Solar irradiant energy & $\mathrm{W}$ \\
\hline $\mathrm{E}_{\text {water }}$ & $\begin{array}{c}\text { Thermal Energy extracted by } \\
\text { water }\end{array}$ & $\mathrm{W}$ \\
\hline $\mathrm{m}_{\text {water }}$ & Mass of water & $\mathrm{Kg} / \mathrm{s}$ \\
\hline $\mathrm{T}_{\text {out }}$ & The output temperature & $\mathrm{K}$ \\
\hline $\mathrm{T}_{\mathrm{in}}$ & The input temperature & $\mathrm{K}$ \\
\hline $\mathrm{C}_{\text {pwater }}$ & Specific heat of water & $4.18 \mathrm{~kJ} / \mathrm{kg} * \mathrm{~K}$ \\
\hline$\eta_{\text {th }}$ & Thermal efficiency. & $\%$ \\
\hline $\mathrm{E}_{\mathrm{PV}}$ & Electrical energy & $\mathrm{W}$ \\
\hline$\eta_{\text {total }}$ & Total efficiency & $\%$ \\
\hline
\end{tabular}

\section{INTRODUCTION}

Solar energy is becoming one of the primary sources of energy replacing fossil fuels. Its versatility, abundance and environmental friendly have made it one of the most promising renewable sources of energy. Egypt is a primer location for solar energy production. The Sahara receives some $2,400 \mathrm{hrs} / \mathrm{year}$ of sunshine, about 1.5 times the 1,000 hrs/year than Europe receives. Egypt is one of the Sun Belt countries receiving between $1970 \mathrm{kWhr} / \mathrm{m}^{2} /$ year in the North and $2600 \mathrm{kWhr} / \mathrm{m}^{2} /$ year in the South [1].

Bakker et al. [2] analyzed a PV/T panel array where heat was extracted from the panels and stored underground in a heat exchanger. In winter, the heat could be extracted from the ground via a heat pump and used to heat potable water and support a floor heating system while increasing the electrical efficiency of the solar panel. Chen et al. [3] developed a hybrid PV/T pump system using refrigerant fluid R134a as the heat carrying fluid. The coefficient of performance (COP) of the heat pump and electrical efficiency of the PV panel was measured at different condensing fluid flow rates and temperatures. Teo et al. [4] investigated a tracking PV panel cooling system, in which the PV panels were cooled by forced convection, with air being the heat carrying fluid, and resulted in a 4-5\% efficiency increase. Yang et al. [5] developed a functionally graded material (FGM) is a PV layer, copper water pipes cast into plastic lumber that was bonded with thermal paste to the backside of a PV/T panel. Cooling water was pumped at various flow rates through the cast copper pipes to decrease the $\mathrm{PV} / \mathrm{T}$ panel temperature thus increasing PV/T panel electrical efficiency by up to $2 \%$. This study also analyzed the thermal efficiency of the closed system design, and reported that a combined thermal and electrical efficiency of $71 \%$ could be achieved, compared to $53-68 \%$ total efficiency of other PV/T concepts.

\section{PROBLEM STATEMENT}

As the sun irradiance is varying across the day reaching its maximum at the normal direction with PV module, the total output power extracted is changing according to this variation. To maximize such an output power, one axial sun- tracking system is suggested. This tracking system provides the orthogonal between the sun and the PV module across the morning hours by controlling the modules using the zenith angle. On the other hand, rising in climate temperature causing a dramatically increase in the modules temperature. This increase is from $10{ }^{\circ} \mathrm{C}$ to $15{ }^{\circ} \mathrm{C}$ higher than the rite temperature which reflects on the PV performance by decreasing its conversion efficiency. To solve such a problem, a high heat capacity fluid is used to cool the modules by passing through pipes in the backside face of the module. This fluid will extract the heat from the panel causing its temperature to decrease, in other words its efficiency will increase. By using hybrid PV/T system another source of energy is generated due to the thermal effect of the fluid passing inside the copper pipers.

\section{MODELLING AND SIMULATION}

Herein, a simulation model for a fixed and tracking hybrid $\mathrm{PV} / \mathrm{T}$ system is presented. A backside water pipe is heated by the influence of the photovoltaic modules results an enhancement in the total conversion efficiency of the solar system with increasing the output water temperature.

\subsection{Mechanical Model}

One axial sun tracking PV modules is presented. The type of PV modules is a polycrystalline ( $\mathrm{Si}$ ) as shown in Figure (1). The system has been simulated using Comsol Multiphysics, 
Solid work and Mat lab programs. This hybrid system consists of four connected PV modules with area 1.0396 m2andthickness is $0.04 \mathrm{~m}$. The effects of cooling system by passing water in the backside copper pipes of $0.012 \mathrm{~m}, 0.013$ $\mathrm{m}$ for inner and outer diameters and $11.6 \mathrm{~m}$ length. A copper pipe material is chosen due to its high thermal conductivity [6], while water is selected as a cooling fluid for its availability and high specific heat constant. For the tracking system, the incident angle is set to be 30ofor winter season and 15oin summer season for maximum irradiance. The sun irradiance is assumed to be Gaussian with a peak of 1000 $\mathrm{W} / \mathrm{m} 2$ at noon while AM $1.5 \mathrm{G}$ is considered for the fixed system [7].

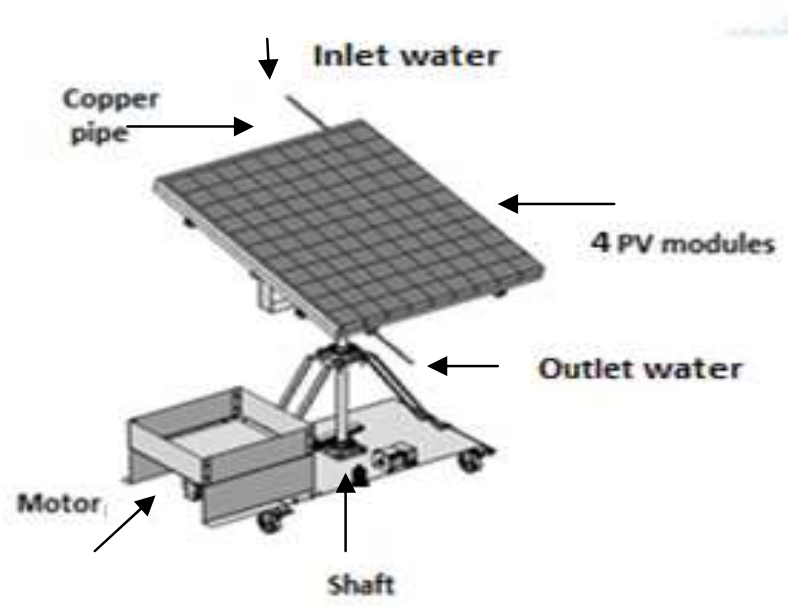

Fig 1: A tracking Polycrystalline PV/T hybrid system used in Comsol

\subsection{PV Model}

Modelling PV system is done through two main phases, the first phase is modelling the optical behaviour of the module and this is done by solving Maxwell's equations using Comsol Multiphysics in three dimensions and determines the absorption coefficient of the material used in modelling the PV (Silicon). The second phase in modelling device characteristics by solving passion equation and getting the I-V characteristics of the device and this is done using Mat lab.

All electromagnetic radiation, including sunlight, is composed of particles called photons, which carry specific amounts of energy determined by the spectral properties of their source. Photons also exhibit a wavelike character with the wavelength, $\lambda$, being related to the photon energy, $\mathrm{E} \lambda$, by [8].

$$
\mathrm{E}_{\lambda}=\frac{\mathrm{hc}}{\lambda}(1)
$$

Only photons with sufficient energy to create an electron-hole pair, those with energy greater than the semiconductor band gap (EG), will contribute to the energy conversion process. Thus, the spectral nature of sunlight is an important consideration in the design of efficient solar cells.

The creation of electron-hole pairs via the absorption of sunlight is fundamental to the operation of solar cells. The excitation of an electron directly from the valence band (which leaves a hole behind) to the conduction band is called fundamental absorption. Both the total energy and momentum of all particles involved in the absorption process must be conserved. Since the photon momentum, $\mathrm{P} \lambda=\mathrm{h} / \lambda$, is very small compared to the range of the crystal momentum, $\mathrm{P}=\mathrm{h} / \mathrm{l}$, the photon absorption process must, for practical purposes, conserve the momentum of the electron. The absorption coefficient $(\alpha)$ for a given photon energy, hv, is:

$$
\alpha(h v)=\sum P_{12} g_{v}\left(E_{1}\right) g_{c}\left(E_{2}\right)(2)
$$

Assuming that all the valence-band states are full and all the conduction-band states are empty. Absorption results in creation of an electron-hole pair since a free electron is excited to the conduction band leaving a free hole in the valence band [9].

The conservation of electron momentum of theindirect band gap semiconductors like $\mathrm{Si}$ and $\mathrm{Ge}$, where the valence-band maximum occurs at a different crystal momentum than the conduction-band minimum, necessitates that the photon absorption process involve an additional particle. Phonons, the particle representation of lattice vibrations in the semiconductor, are suited to this process because they are lowenergy particles with relatively high momentum. Notice that light absorption is facilitated by either phonon absorption $\left(\alpha_{\mathrm{ab}}\right)$ or phonon emission $\left(\alpha_{\mathrm{em}}\right)$. The absorption coefficient, when there is phonon absorption and emission, are given by:

$$
\begin{gathered}
\alpha_{\mathrm{ab}}(\mathrm{hv})=\frac{\left(\mathrm{hv}-\mathrm{E}_{\mathrm{G}}+\mathrm{E}_{\mathrm{P}}\right)^{2}}{\mathrm{E}_{\mathrm{P}}}(3) \\
\mathrm{e}_{\mathrm{em}}(\mathrm{h} v)=\frac{\left(\mathrm{h} v-\mathrm{E}_{\mathrm{G}}-\mathrm{E}_{\mathrm{P}}\right)^{2}}{1-\mathrm{e}^{-\frac{\mathrm{E}_{\mathrm{P}}}{\mathrm{K}_{\mathrm{B}} \mathrm{T}}}(4)} \\
\mathrm{E}_{\mathrm{p}}=\frac{\mathrm{h} v_{\mathrm{th}}}{\lambda}(5) \\
\alpha(\lambda)=\alpha_{\mathrm{ab}}+\alpha_{\mathrm{em}}(6)
\end{gathered}
$$

Since both a phonon and an electron are needed to make the indirect gap absorption process possible, the absorption coefficient depends not only on the density of full initial electron states and empty final electron states but also on the availability of phonons (both emitted and absorbed) with the required momentum. Thus, compared to direct transitions, the absorption coefficient for indirect transitions is relatively small. As a result, light penetrates more deeply into indirect 
band gap semiconductors than direct band gap semiconductors.

In practice, measured absorption coefficients or empirical expressions for the absorption coefficient are used in analysis and modelling. The rate of creation of electron-hole pairs (number of electron-hole pairs per $\mathrm{cm} 3$ per second) as a function of position within a solar cell is:

$$
\mathrm{G}(\mathrm{x})=(1-\mathrm{s}) \int(1-\mathrm{r}(\lambda)) \Gamma(\lambda) \alpha(\lambda) \mathrm{e}^{-\alpha \mathrm{x}} \mathrm{d} \lambda(7)
$$

Here, the absorption coefficient has been casted in terms of the light's wavelength through the relationshiph $\mathrm{v}_{\mathrm{v}}=\mathrm{h}_{\mathrm{c}} / \lambda$. The photon flux, $\Gamma(\lambda)$, is obtained by dividing the incident power density at each wavelength by the photon energy. Regarding the semiconductor behaviour of the device equation (8), repeated here, is a general expression for the current produced by a solar cell [8].

$$
\mathrm{I}=\mathrm{I}_{\mathrm{sc}}-\mathrm{I}_{01}\left(\mathrm{eq} \frac{\mathrm{V}}{\mathrm{KT}}-1\right)-\mathrm{I}_{02}\left(\mathrm{eq} \frac{\mathrm{v}}{2 \mathrm{KT}}-1\right)(8)
$$

The short circuit current and dark saturation currents are given by rather complex expressions that depend on the solar cell structure, material properties, and the operating conditions. A full understanding of solar cell operation requires detailed examination of these terms. However, much can be learned about solar cell operation by examining the basic form of equation (8).

From a circuit perspective, it is apparent that a solar cell can be modelled by an ideal current source (ISC) in parallel with two diodes - one with an idealist factor of " 1 " and the other with an idealist factor of " 2 ". Note that the direction of the current source is opposed to the current flow of the diodes that is, it serves to forward-bias the diodes.

Solar cell efficiency, $\eta$, is defined as the ratio of electrical power out (at an operating condition of maximum power output), Pout, divided by total optical power in, Pin, typically under AM1.5G.AM1.5G stands for Air Mass 1.5 [7], Global illumination. "Air Mass 1.5" indicates that the sunlight has been attenuated by passage through the Earth's atmosphere a distance equal to 1.5 times the shortest path (when the sun is directly overhead). "Global" indicates that both direct and diffuse components of sunlight are included:

$$
\eta_{\text {electric }}=\frac{\mathrm{P}(\text { out })}{\mathrm{P}(\mathrm{in})}=\frac{\mathrm{V}_{\mathrm{oc}} * \mathrm{Jsc}_{\mathrm{sc}} * \mathrm{FF}}{\mathrm{P}(\mathrm{in})}(9)
$$

\subsection{Thermal Model}

In this study, forced convection does not only occur on the top surface of the PV panel, but also through the pipe mounted to the backside of the panel. Therefore, the total convective heat transfer is a combination of the heat transfer at the surface of the panel and the heat transfer from the flowing water in the pipe. The finite element analysis software being used in this study, Comsol Multiphysics contains an open system laminar flow and conjugate heat transfer physics package, which is being used to model the convective heat transfer in the water pipe on the backside of the PV panel. This package is appropriate for this study, because of the inhomogeneous temperature field that is created as water flows from the inlet to the outlet of the pipe. Comsol numerically solves the fully compressible continuity and momentum equations, which are the governing equations for the fluid flow, and are shown below in equations (10 and 11), shown in [6].

$$
\begin{gathered}
\frac{\mathrm{d} \rho}{\mathrm{dt}}=\nabla \cdot(\rho \mathrm{u})=0(10) \\
\rho \frac{\mathrm{du}}{\mathrm{dt}}+\rho \mathrm{u} \cdot \nabla \mathrm{u}= \\
-\nabla \mathrm{p}+\nabla \cdot\left(\mu\left(\nabla \mathrm{u}+(\nabla \mathrm{u})^{\mathrm{T}}\right)-\right. \\
23 \mu \nabla \cdot \mathrm{u} I(11)
\end{gathered}
$$

The heat equation is also solved, which is shown in equation (12).

$$
\rho \mathrm{C}_{\mathrm{p}} \mathrm{u} \cdot \nabla \mathrm{T}=\nabla \cdot(\mathrm{K} \nabla \mathrm{T})(12)
$$

The long wave radiation heat loss can be calculated from equation (13).

$$
\mathrm{q}_{\mathrm{lw}}=\varepsilon \cdot \sigma \cdot\left(\mathrm{T}_{\mathrm{PV}}^{4}-\mathrm{T}_{\mathrm{amp}}^{4}\right)(13)
$$

A numerical model based on Comsol Multiphysics simulation tool [10] for a hybrid PV/T is introduced as shown in Figure (2). The silicon PV modules are heated by the electromagnetic waves produces by the sun through radiation heat transfer. This heated body (PV modules) transfers its heat to the aluminium plate and the copper pipe surface (outer and inner) by conduction. Finally the cooling liquid (water) is heated by convection where the heat loses and the surrounding radiations are ignored. The overall heat transfer coefficient is given by equation (14, 15 and 16) and the rate of heat transfer calculated by equation (17) for an open thermodynamic system [6].

$$
\begin{aligned}
\frac{1}{U A}= & \frac{t_{h}}{K_{S i} A}+\frac{t_{h}}{K_{\text {Al }} A}+\frac{\ln \left(\frac{\mathrm{r}_{\text {in }}}{\mathrm{r}_{\text {out }}}\right)^{2}}{2 \pi K_{\text {Pipe }} L}+\frac{1}{h_{\mathrm{W}} \mathrm{a}}+\frac{1}{h_{\text {air }} \mathrm{a}}(14) \\
\mathrm{A} & =1 \times \mathrm{W} \\
\mathrm{a} & =2 \pi \mathrm{rL} \\
\mathrm{Q} & =\mathrm{AU} \Delta \mathrm{T}
\end{aligned}
$$



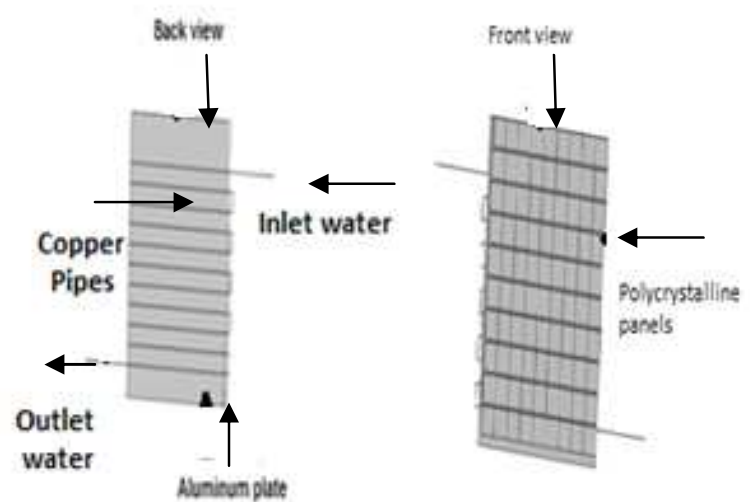

Fig (2): Front and back view for a PV/T system used in Comsol.

The thermal model modelled in this study is identical to that modelled by Jones and Underwood [11], although the amount of energy applied to the PV cell that is converted to heat energy is calculated using the same method Kerzmann and Schaefer [12] utilize. The heat energy going into the PV cell is a function of the PV cell efficiency, $\eta_{\mathrm{PV}}$, as shown below in equation (19) Using this calculated value for the PV cell efficiency, the amount of solar irradiance, $\mathrm{q}_{\mathrm{rad}}$ that is converted to heat energy, $Q_{\text {heat }}$ isthen calculated at each time step from equation (18). The steady state solution is finally reached as the Comsol solver converges.

$$
\mathrm{Q}_{\text {heat }}=\mathrm{q}_{\mathrm{rad}}\left(1-\eta_{\mathrm{pv}}\right)(18)
$$

The PV cell electrical output efficiency can also be expressed as a function of PV cell power output, solar irradiance, and the PV cell surface area as shown in equation (19).

$$
\eta_{\mathrm{PV}}=\frac{\mathrm{V}_{\mathrm{mp}} \mathrm{I}_{\mathrm{mp}}}{\mathrm{q}_{\mathrm{rad}} \mathrm{A}}(19)
$$

Post processing of the data recorded in the simulations is required to calculate the thermal efficiency, $\eta_{\mathrm{th}}$, of the PV/T panel [9]. First, the total amount of energy (solar irradiance) into the cell must be calculated, which is given by equation (20).

$$
\mathrm{E}_{\text {in }}=\mathrm{q}_{\mathrm{rad}} \mathrm{A}(20)
$$

Next, the thermal energy of the extracted by the water per second must be calculated from equation (21).

$$
\mathrm{E}_{\text {water }}=\mathrm{m}_{\text {water }} \mathrm{C}_{\text {pwater }}\left(\mathrm{T}_{\text {out }}-\mathrm{T}_{\mathrm{in}}\right)(21)
$$

The mass of the water passing through the reservoir per second can be calculated from the density and flow rate of the water, assuming unit depth of the reservoir. The thermal efficiency is simply given by equation (22).

$$
\eta_{\text {th }}=\frac{E_{\text {water }}}{E_{\text {in }}}(22)
$$

Similarly, the quantity of the total input energy converted to electrical energy can be approximated from the solution data by obtaining the average electrical efficiency of the PV/T panel, a COMSOL derived value taken across the top layer of the model, and multiplying it by the total energy into the panel, $E_{\text {in }}$. This is shown by equation (23).

$$
\mathrm{E}_{\mathrm{PV}}=\eta_{\mathrm{PV}} \mathrm{E}_{\mathrm{in}}(23)
$$

The total efficiency of the PV/T panel is then computed from equation (24).

$\eta_{\text {total }}=\frac{E_{\text {water }}+E_{P V}}{E_{\text {in }}}(24)$

Using equations (22 and 24) the thermal and the total efficiency are simulated.

\section{THE PROPOSED TECHNIQUES FOR ENHANCING THE EFFICIENCY}

Two techniques are used to enhance the efficiency of the PV thermal system. First enhancing the tracking of the hybrid PV/T system by zenith angle and second decreasing the temperature of back surface for PV modules.

\subsection{Tracking System}

A closed loop control system of the hybrid PV thermal system has been designed to track the zenith angle [13]. Figure (3) shows the designed control system where a PID controller has been done. The block diagram of closed loop control contains DAQ, potentiometer and simple circuit assisted the motor to rotate shaft for facing the Sun irradiance. Figure (4) shows the place of the potentiometer used to feedback the angle of PV thermal system.

The mathematical description of PID control is given by equation (25):

$$
u(t)=K_{p}\left[e(t)+T_{i} \int_{0}^{t} e(\tau) d+T_{d} \frac{d e(t)}{d(t)}\right](25)
$$

\subsection{Decreasing the Temperature of Back Surface for PV Modules}

To decrease the temperature of back surface of PV modules used four temperature sensors (LM 35) are used and placed on the surface of four PV modules to control solenoid valve by PWM (Pulse Width Modulator) as shown in Figure (5). Figure (6) shows the place of electrical valve in the PV thermal system. Beside that two thermistors are located in inlet and outlet copper pipes to calculate the heat generated from PV 
modules. The mathematical description of $\mathrm{Q}_{\text {heat }}$ is given by equation (26):

$\mathrm{Q}_{\text {heat }}=\mathrm{m} \cdot \mathrm{Cp} \Delta \mathrm{T}(26)$
And then calculate the thermal power generated from PV panels by equation (27):

$$
\mathrm{P}_{\text {thermal }}=\mathrm{Q}_{\text {heat }} / \text { time }^{(27)}
$$

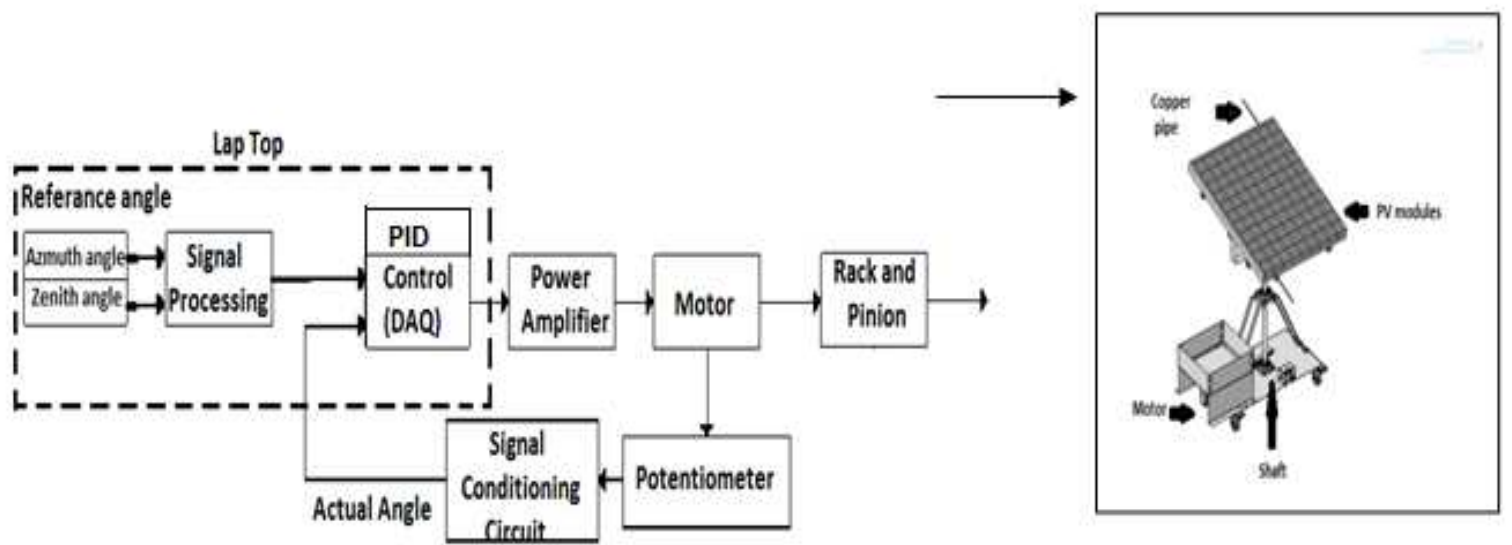

Fig (3): Closed loop block diagram for controlling the motor.

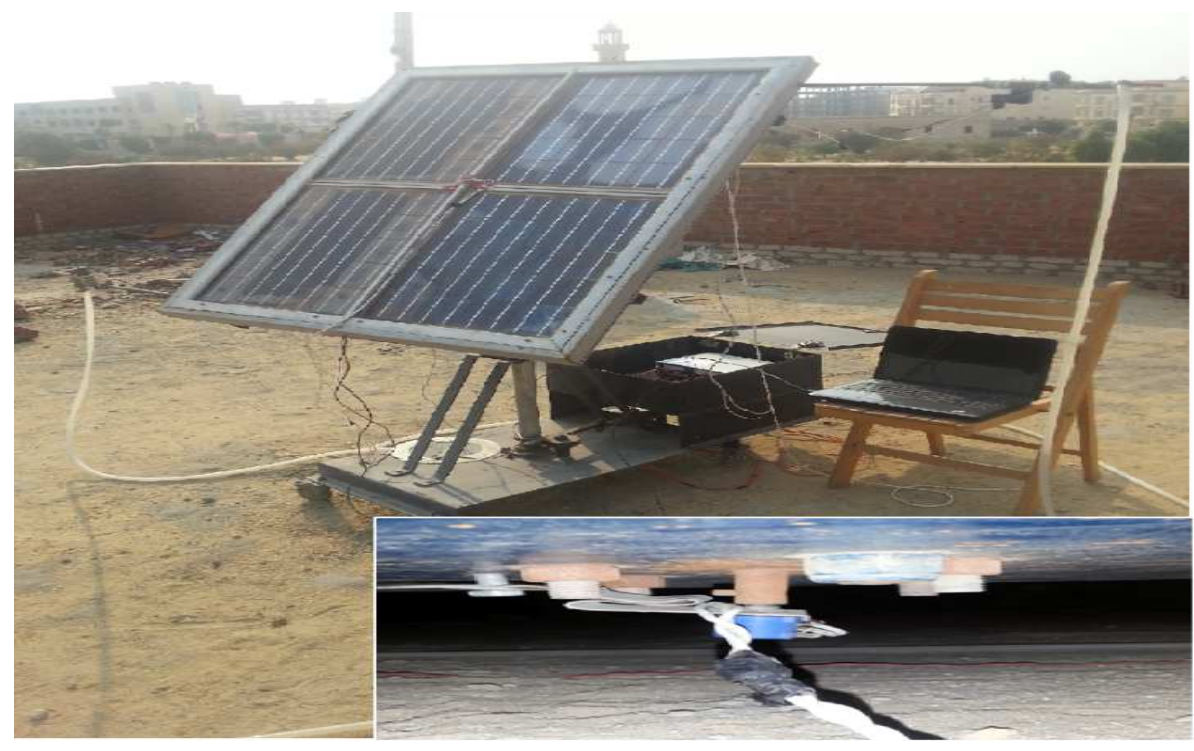

Fig (4): Place of Potentiometer to control the PV thermal system.

\section{HYBRID PV/T EXPERIMENTAL SETUP}

Figure (7) shows the experimental set-up designed to investigate how the temperatureaffects the efficiency and power output of PV panel during operation and takes advantage of these heat losses. The system mounted on a roof of a building in a sub-urban area near Cairo. A PV/T system designed as one axial active tracking [14]. During the operation, a mechanical tracking system was used to modulate the power output from solar panel by regulating the position of the photovoltaic module facing the sun. In other words this mechanical system makes the zenith angleapproaches to zero from sun rise to sun set to ensure that the maximum electrical power is extracted depends on solar irradiance as arrange from 
$400 \mathrm{~W} / \mathrm{m}^{2}$ to $980 \mathrm{~W} / \mathrm{m}^{2}$.A hybrid system combined between PV and cooling systems was designed to cool the modules.

The experiment was conducted from 6:00 am to 6:00 pm. A solar power meter was used to capture the daily global solar irradiance. Temperature measurements are important in these experiments and therefore calibrated K-type thermocouples were utilized. In the experiments, PV current, PV voltage, water input and output temperatures, PV surface temperatures and solar irradiance were collected. All the experimental test rig components that used have been calibrated. Readings were collected from June 2013 to January 2014.

In order to provide one axial rotation tracker, a closed loop control system is used. A 5 volt potentiometer is fixed inside the spindle perpendicularly to detect the angle of rotation. The potentiometer voltage is acquired to a NI DAQ 6008 and calibrated into the corresponding angle. Then a PID controller is chosen to control the system using a previously calculated reference angle as shown in Figure (8).

In order to maximize the electrical power extracted from the $\mathrm{PV}$ modules, a solenoid valve is used to control the water flow by acquiring the PV surface temperatures using a 5 volt (LM 35). The temperature sensorsignal (from LM 35) acquired to the Lab view through the NI DAQ to be calibrated. Pulse width modulation (PWM) is used to control the opening duration of the valve by varying the duty cycle of a square wave generated by Lab view. The frequency of the PWM is chosen to be $50 \mathrm{~Hz}$ as required by the solenoid valve. The Lab view block diagram shown in Figures (9). The input and output water temperatures is measured through a 5 volt thermistor and acquired to the lab view throw the NI DAQ to be used in calculating the total amount of energy losses from the PV modules to the water.

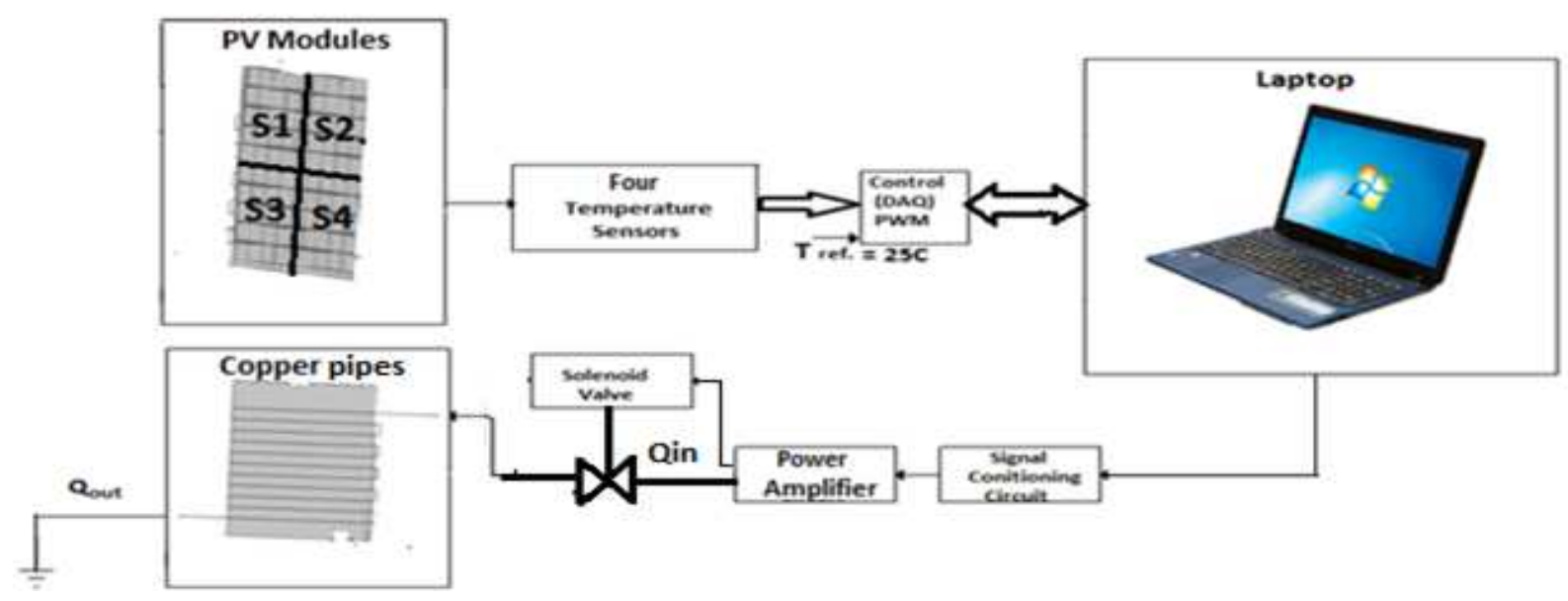

Fig (5): Closed loop block diagram for decreasing the temperature of back surface of PV modules

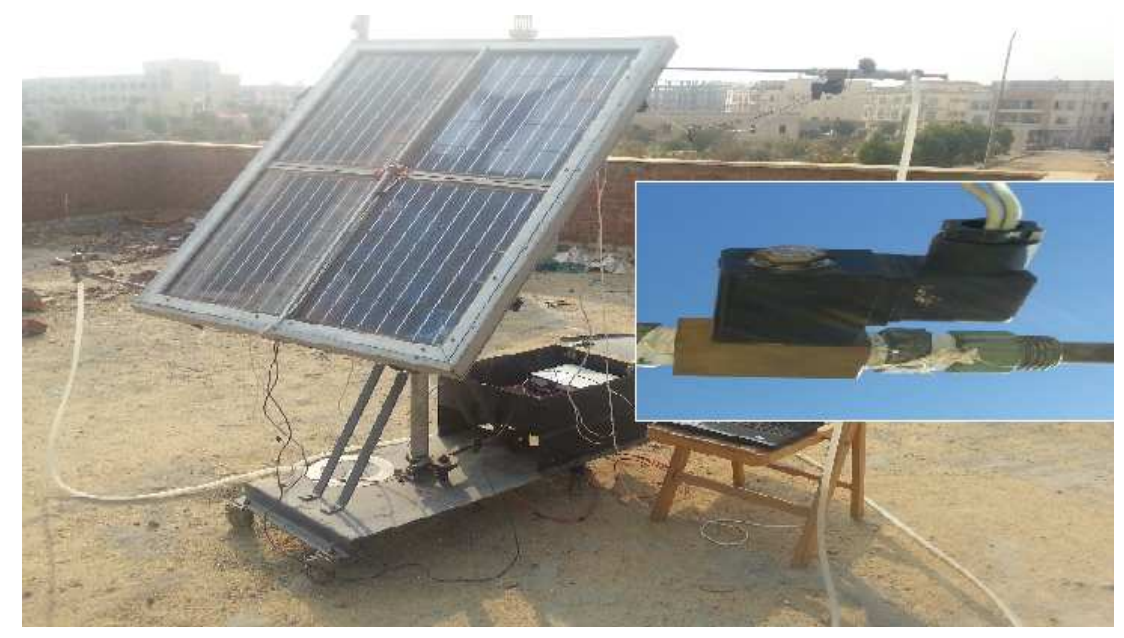

Fig (6): Place of electrical valve used to decrease the temperature of PV surface modules. 


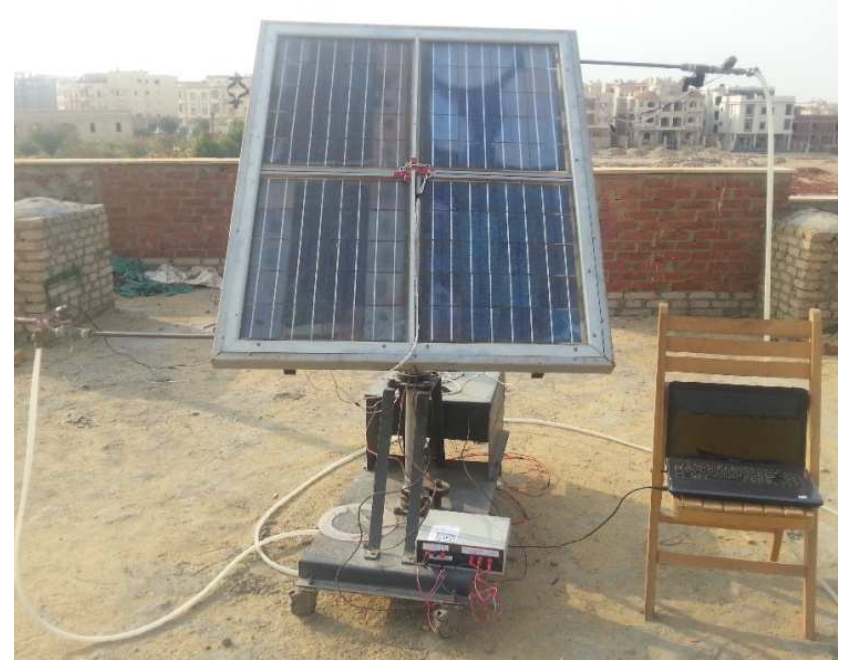

Fig (7): General view of the experimental system used.

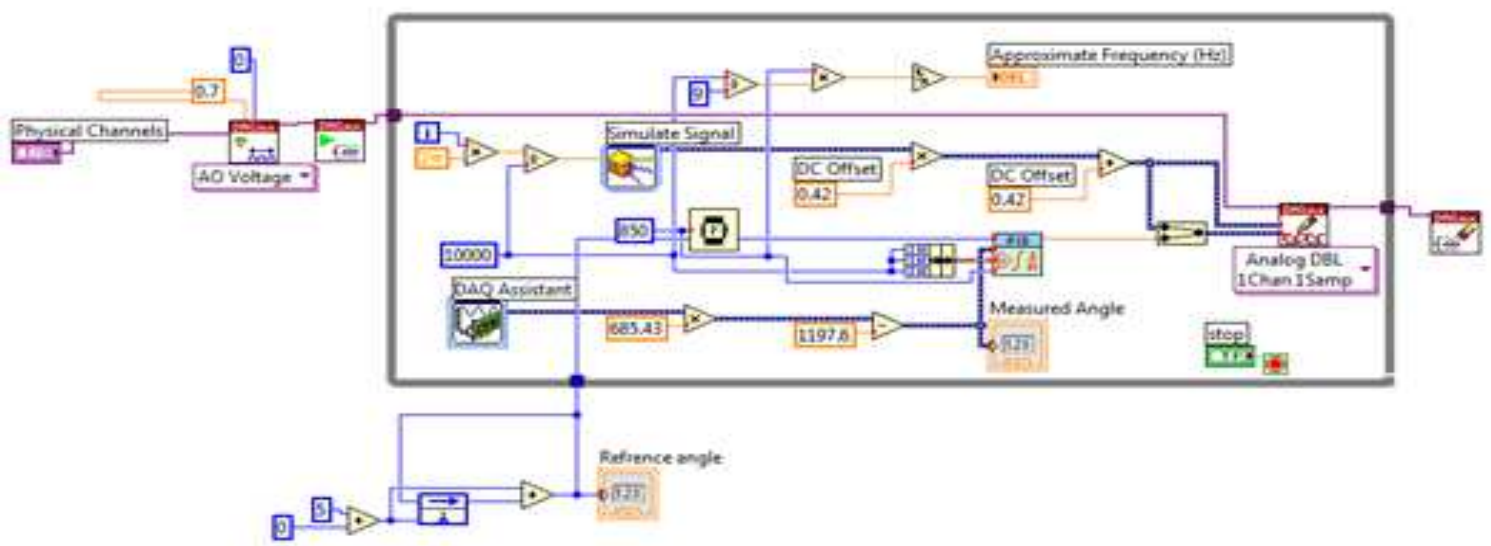

Fig (8): Closed loop block diagram for decreasing the temperature of back surface of PV modules.

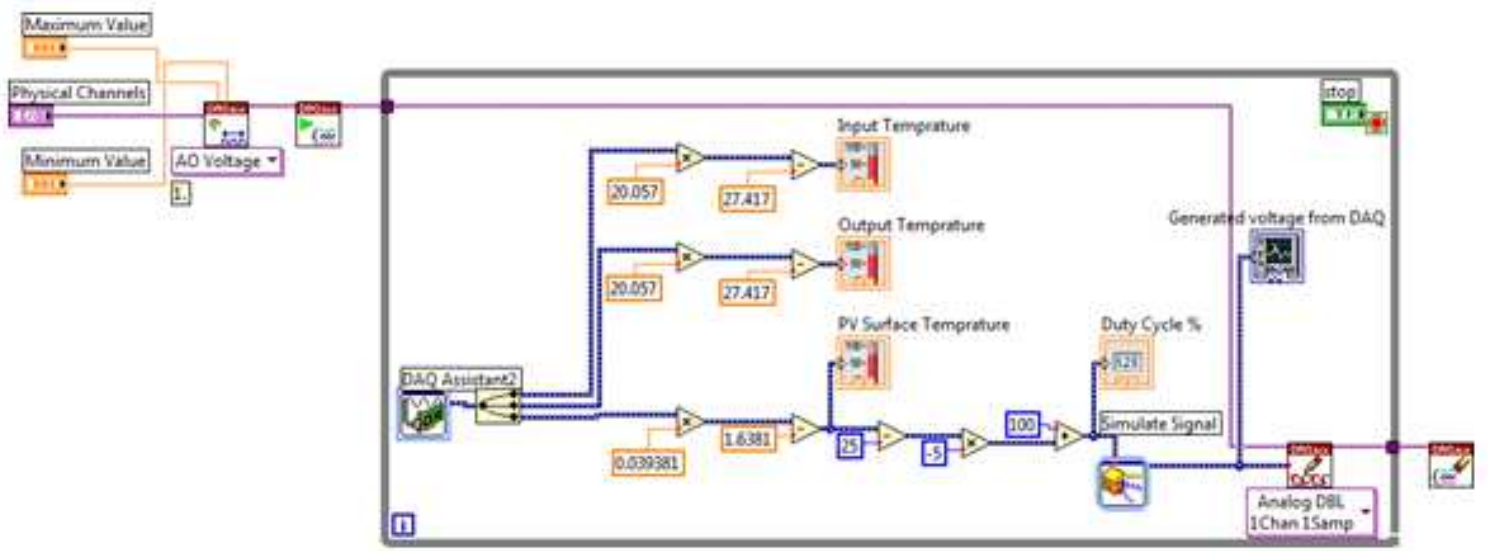

Fig (9): Closed loop block diagram for decreasing the temperature of back surface of PV modules. 


\section{RESULTS AND DISCUSSION}

\subsection{Tracking Response}

Figure (10) shows the response of the tracking control system where $K_{p}=3, K_{i}=0.63$ and $K_{d}=0.0086$. The PID controller shows a zero steady-state error as response to step input. The maximum over shot 93 degree and occurred at $\mathrm{T}_{\mathrm{m} . \mathrm{s} . \mathrm{s}}=3.1 \mathrm{sec}$. The $K_{p}$ responsible for increases the responses speed of the motor, the overshoot of the closed loop system increases [15].

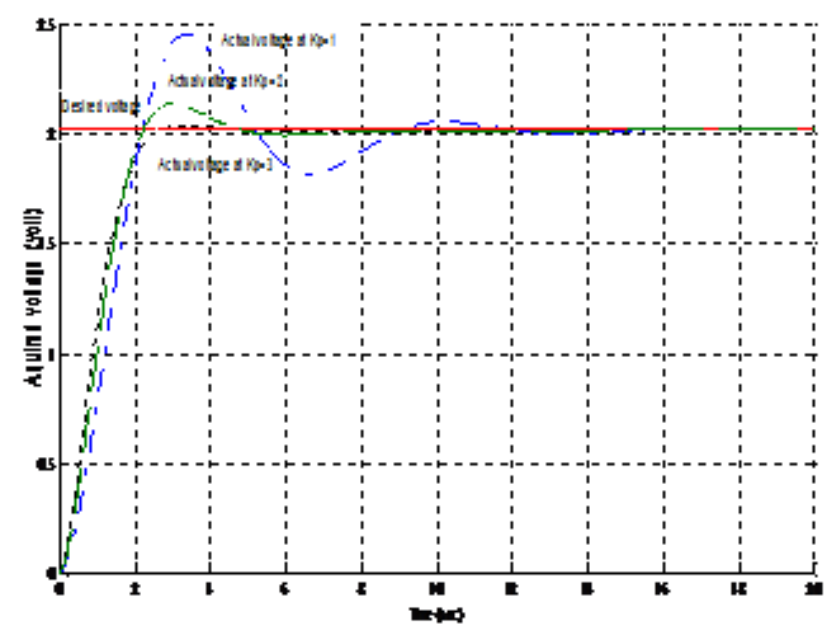

Fig (10): Acquired voltage vs. duration time response for PID control.

To examine the utility of the PV tracker based on a potentiometer, the reference angle is plotted verse the actual angle as shown in Figures (11) and the error is calculated shown in Figure (12). As expected the error various from 0 to $9 \%$ as we go toward extremes either to left or to right. A minimum error is recorded at noon angle where the efficiency can be observed from the graph that the error doesn't exceed $10 \%$ which indicated that the used technique is an efficient one to track the sun across the day.

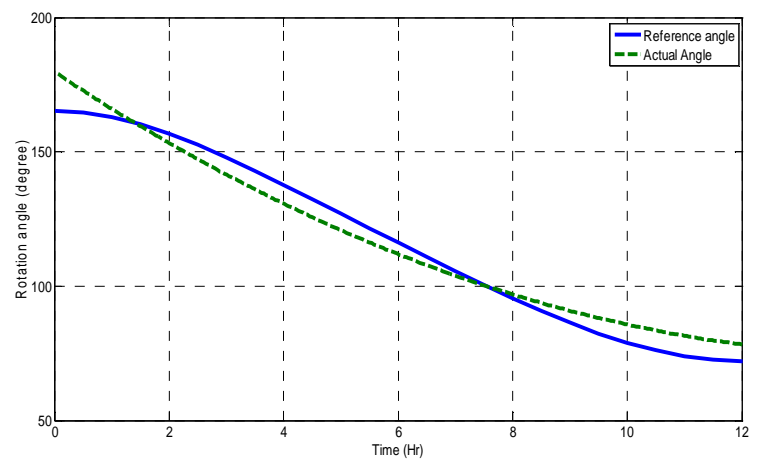

Fig (11): Rotation angle verses 12 hours mourning.

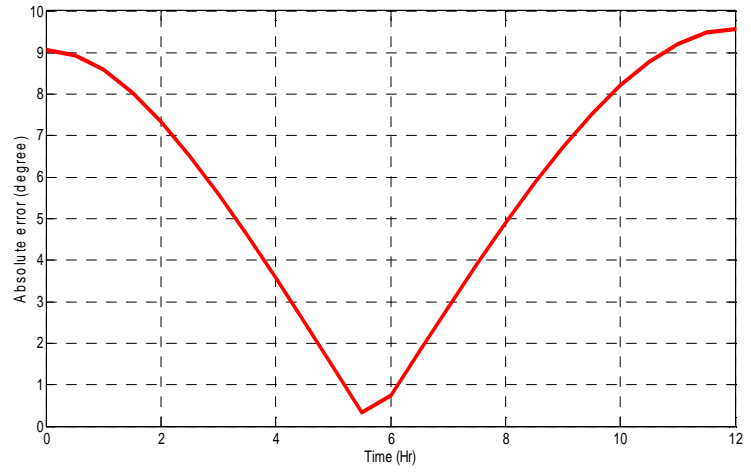

Fig (12): Absolute error verses 12 hours mourning.

\subsection{I-V AND P-V Characteristics Curves for}

\section{Theoretical and Experimental Results}

The I-V and P-V measured experimentally under difference irradiance are compared with the corresponding simulation results as shown Figure (13). This comparison shows an acceptable response between the experimental and theoretical results. It can be observed from the graph that the impact of the Sun irradiance is reflected on the short circuit current with low effect on the opencircuit voltage. The higher Sun irradiance is the higher short circuit current. It has to be mentioned here that the differencebetween the experimental and simulation results is due to the limited number of measured data that is taken in the experimentalresults as the high power resistors are of fixed tendered values.
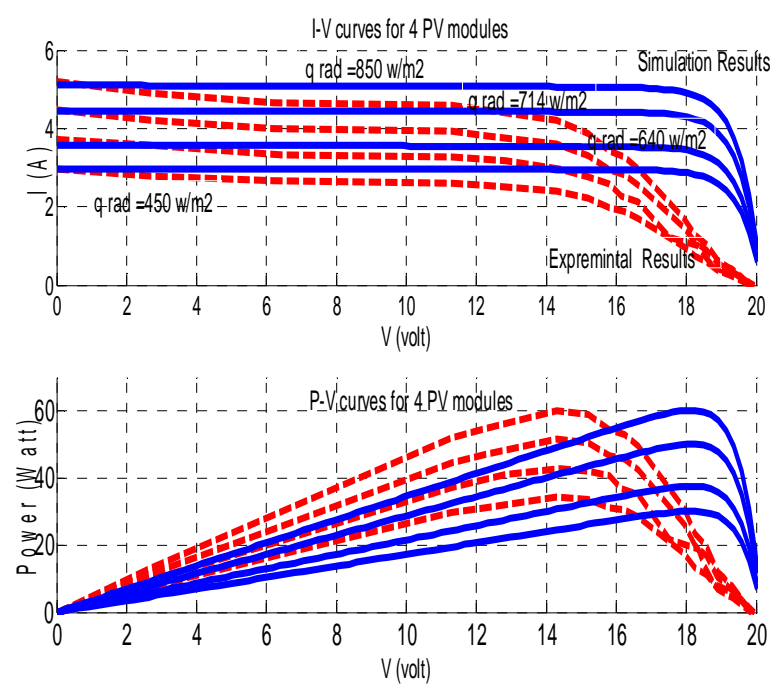

Fig 13: Comparison between $I-V$ \& $P-V$ curves for fixed and tracking PV/T hybrid system 


\subsection{Theoretical and Experimental Results for Output}

\section{Powers and Related Efficiencies}

\subsubsection{Without Cooling}

Figure (14) provide a comparison between theoretical and experimental work of fixed and tracking systems without cooling. This comparison shows an acceptable response between the experimental and theoretical results. The tracking system shows an improvement of about $20 \%$ in the output electrical power with respect to the fixed system. This enhancement in the Pout is reflected on electrical efficiency of the PV modules as shown in Figure (15).

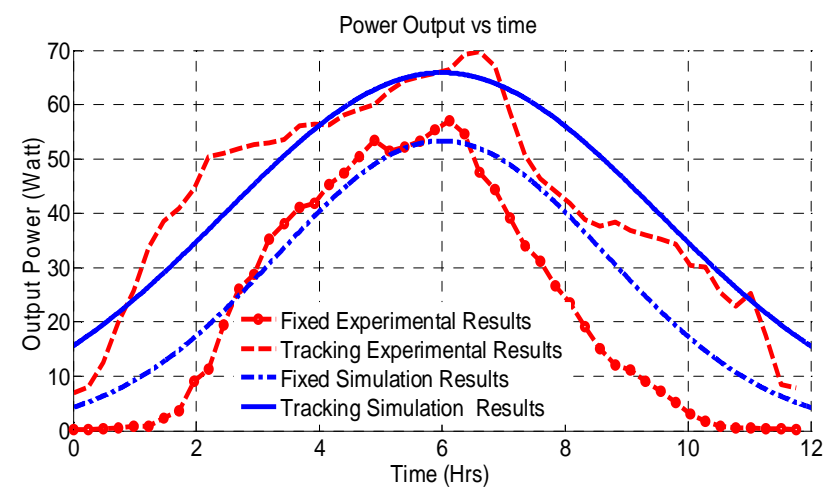

Fig 14: Comparison between simulation \& experimental results for Pout with 12 hour's mourning for Fixed \& tracking $\mathrm{PV} / \mathrm{T}$ system without cooling on $31^{\text {st }}$ December $\& 1^{\text {st }}$ January.

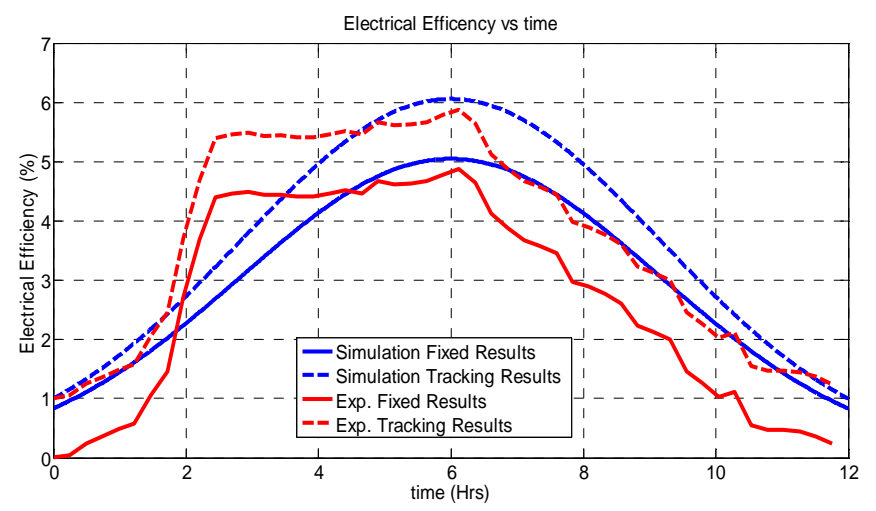

Fig15: Comparison between simulation \& experimental results for electrical efficiencies with 12 hour's mourning for Fixed \& tracking PV/T system without cooling on $31^{\text {st }}$ December $\& 1^{\text {st }}$ January.

\subsubsection{With the Enhanced Hybrid System}

Figure (16) provide a comparison between theoretical and experimental work of fixed and tracking systems with cooling but without controlling on the flow rate inside the copper pipes. This comparison shows a great accordance between this case and previous one (without cooling). This comparison shows an acceptable response between the experimental and theoretical results. The tracking system shows an improvement of about $30 \%$ in the output electrical power with respect to the fixed system. This enhancement in the Pout is reflected on electrical efficiency of the PV modules as shown in Figure (17). By comparing both with (without using controlling system) and without cooling systems, it can be observed that a cooling system records a higher system enhancement of $7 \%$ compared to without cooling case.

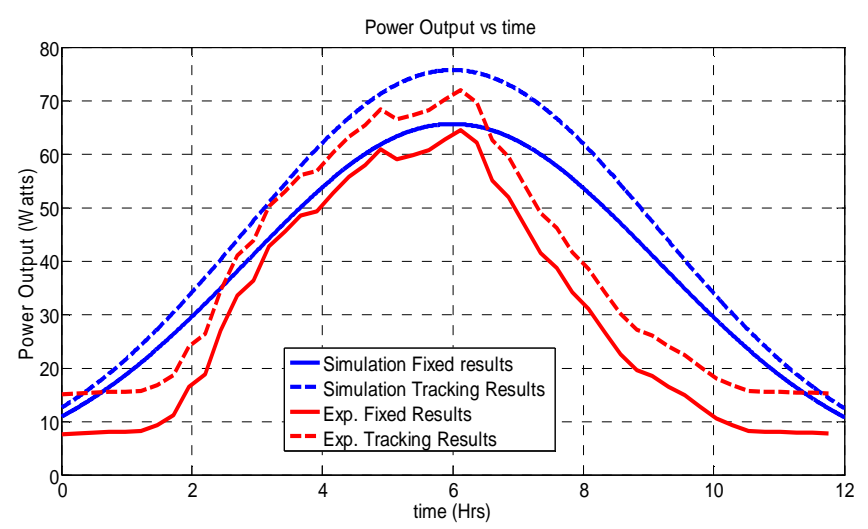

Fig16: Comparison between the power outputs with 12 hour's morning for fixed and tracking PV-modules without controlling the flow rate in the pipes cooling on $14^{\text {th }}$ January $\& 15^{\text {th }}$ January

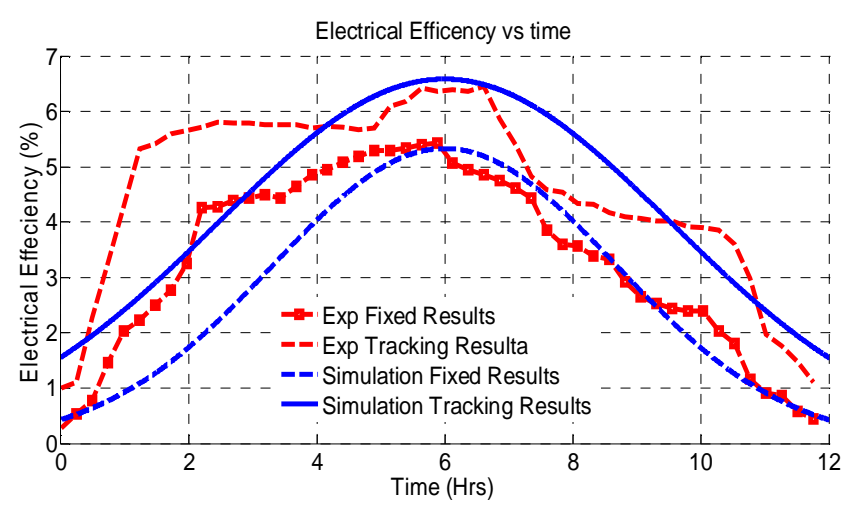

Fig 17: Comparison between the electrical efficiencies with 12 hour's morning for fixed and tracking PV-modules without controlling the flow rate in the pipes cooling on $14^{\text {th }}$ January $\& 15^{\text {th }}$ January.

For thermal analysis, the output temperatures are measured under both fixed and tracking systems and compared with the corresponding simulation results as shown in Figure (18). This comparison shows an acceptable response between the experimental and theoretical results $15 \%$ increase in the output temperature is observed due to tracking. The thermal power generated from PV panels calculated from $Q_{\text {heat }}$ as shown in Figure (19). This achievement in thermal power due to the 
water passing throws the pipes cooling continuously. It reached to $11 \%$ in case of fixed system while it observed to $18 \%$ in tracking system. This improvement causes a $20 \%$ increased in the thermal efficiency so that a $62 \%$ thermal efficiency is detected as shown in Figure (20) for the tracking system while that of the fixed system is only $48 \%$. Finally the total efficiency is calculated in Figure (21) as the sum of the electrical and thermal efficiencies. A $20 \%$ enhancement in the total efficiency is observed, which is considered a big improvement of PV/T system.

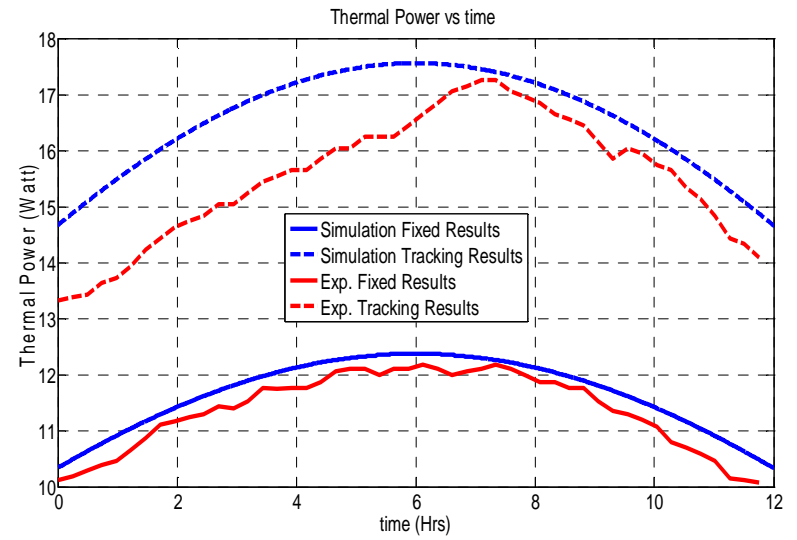

Fig 18: Comparison between the output water temperatures with 12 hour's morning for fixed and tracking PV-modules without controlling the flow rate in the pipes cooling on $14^{\text {th }}$ January $\& 15^{\text {th }}$ January.

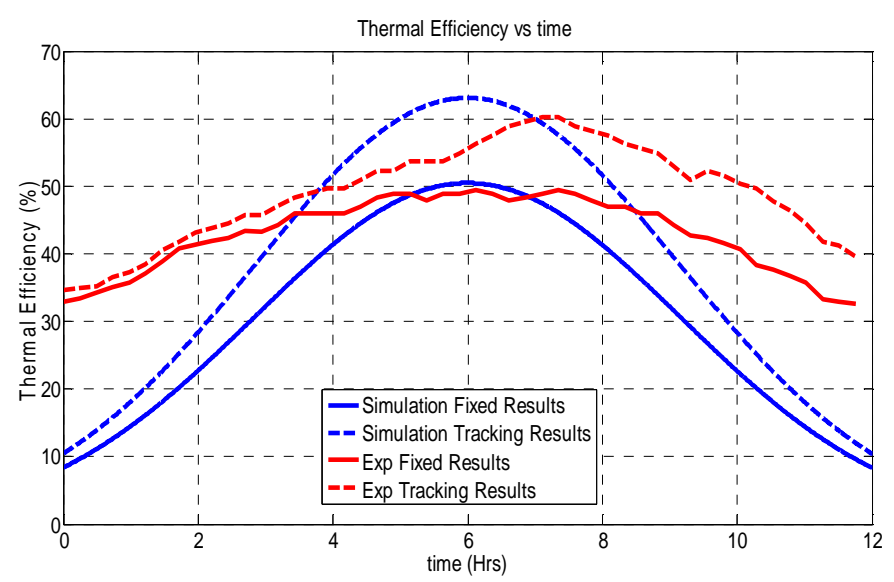

Fig19: Comparison between the thermal powers generated from PV panels with 12 hour's morning for fixed and tracking $\mathrm{PV}$-modules without controlling the flow rate in the pipes cooling on $14^{\text {th }}$ January $\& 15^{\text {th }}$ January

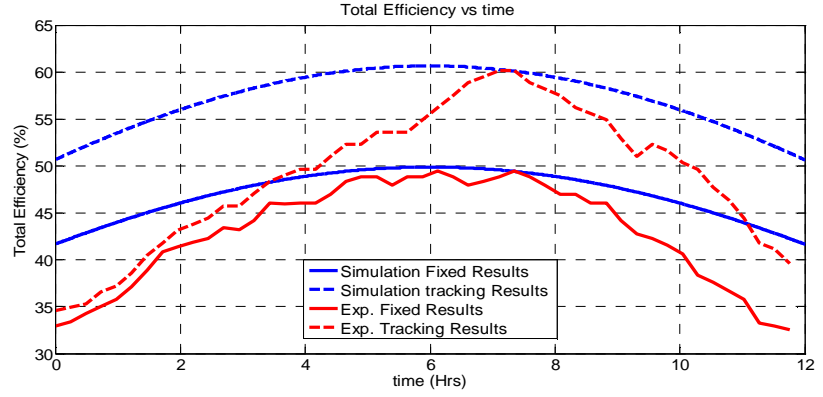

Fig 20: Comparison between the thermal efficiencies with 12 hour's morning for fixed and tracking PV-modules without controlling the flow rate in the pipes cooling on $14^{\text {th }}$ January $\& 15^{\text {th }}$ January.

\subsubsection{Decreasing The Temperature of Back Surface for PV Modules Results}

Figure (21) provide a comparison between theoretical and experimental work of fixed and tracking systems with cooling but with controlling on the flow rate inside the copper pipes by means with using the electrical valve and the sensors on the surface of PV panels. The controller assists the electrical valve to open and closed by PWM. The flow rate of water got inside the copper pipes by different flow. This comparison shows a great accordance between this case and previous one (without controller). This comparison shows an acceptable response between the experimental and theoretical results. The tracking system shows an improvement of about $30 \%$ in the output electrical power with respect to the fixed system. This enhancement in the Pout is reflected on electrical efficiency of the PV modules as shown in Figure (22). By comparing both with (with controller) and without cooling systems, it can be observed that a cooling system records a higher system enhancement of $17 \%$ compared in case of without cooling

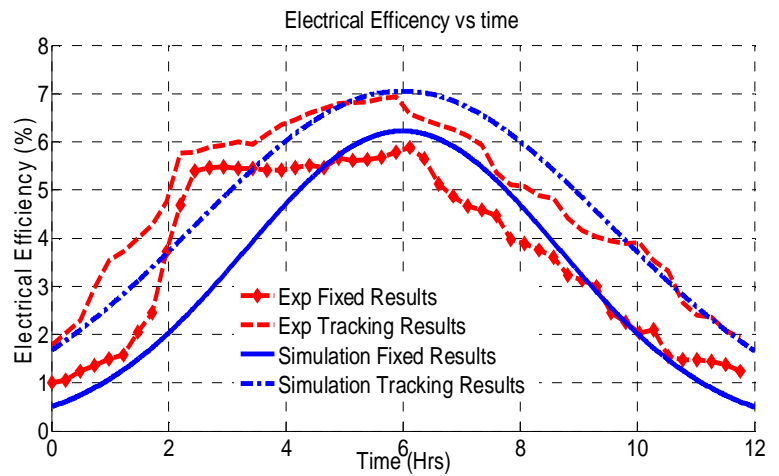

Fig21: Comparison between simulation \& experimental results for Pout with 12 hour's mourning for Fixed \& tracking $\mathrm{PV} / \mathrm{T}$ system with cooling on $31^{\text {st }}$ December $\& 1^{\text {st }}$ January. 


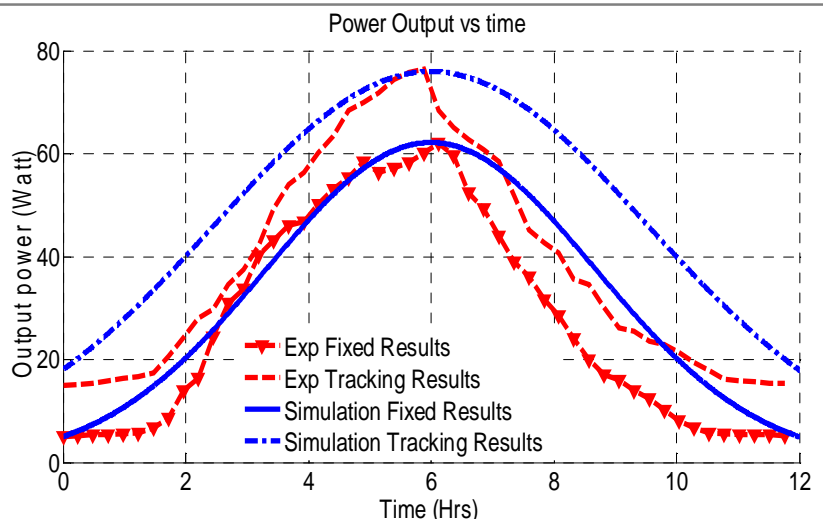

Fig 22: Comparison between simulation \& experimental results for electrical efficiencies with 12 hour's mourning for Fixed \& tracking PV/T system with cooling on $31^{\text {st }}$ December $\& 1^{\text {st }}$ January.

For thermal analysis, the output temperatures are measured under both fixed and tracking systems and compared with the corresponding simulation results as shown in Figure (23). This comparison shows an acceptable response between the experimental and theoretical results $30 \%$ increased in the output temperature is observed due to tracking. The thermal power generated from PV panels calculated from $Q_{\text {heat }}$ as shown in Figure (24). This achievement in thermal power due to the water passing throws the pipes cooling by PWM. It reached to $6 \%$ in case of fixed system while it observed to $9 \%$ in tracking system. This improvement causes a $30 \%$ increase in the thermal efficiency so that a $78 \%$ thermal efficiency is detected as shown in Figure (25) for the tracking system while that of the fixed system is only $61 \%$. Finally the total efficiency is calculated in Figure (26) as the sum of the electrical and thermal efficiencies. A $30 \%$ enhancement in the total efficiency is observed, this improvement is considered the main achievement in this work.

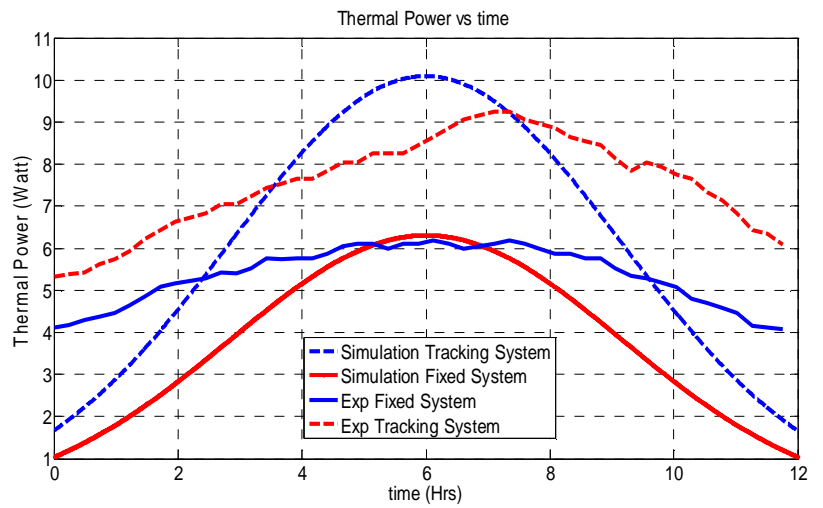

Fig 23: Comparison between the output temperatures with 12 hour's morning for fixed and tracking PV-modules with pipes cooling on $31^{\text {st }}$ December $\& 1^{\text {st }}$ January.

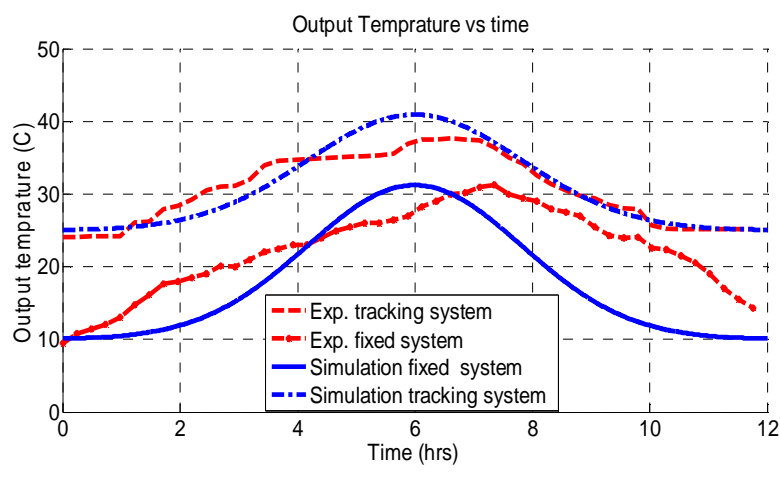

Fig 24: Comparison between the thermal powers generated from PV panels with 12 hour's morning for fixed and tracking $\mathrm{PV}$-modules with controlling the flow rate in the pipes cooling on $14^{\text {th }}$ January $\& 15^{\text {th }}$ January.

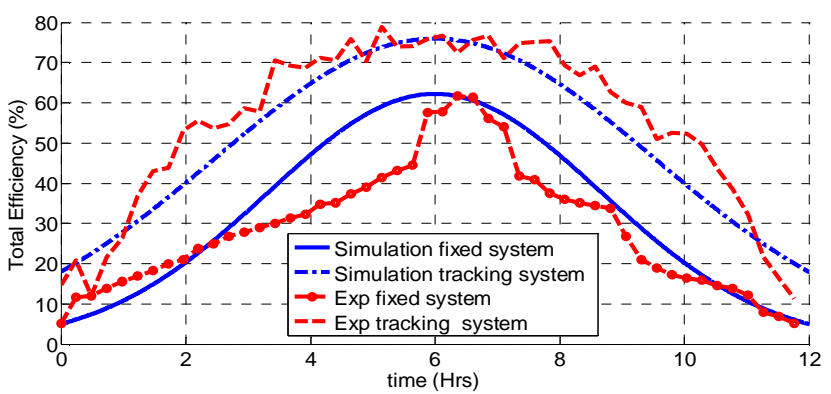

Fig 25: Comparison between the thermal efficiencies with 12 hour's morning for fixed and tracking PV-modules with pipes cooling on $31^{\text {st }}$ December $\& 1^{\text {st }}$ January.

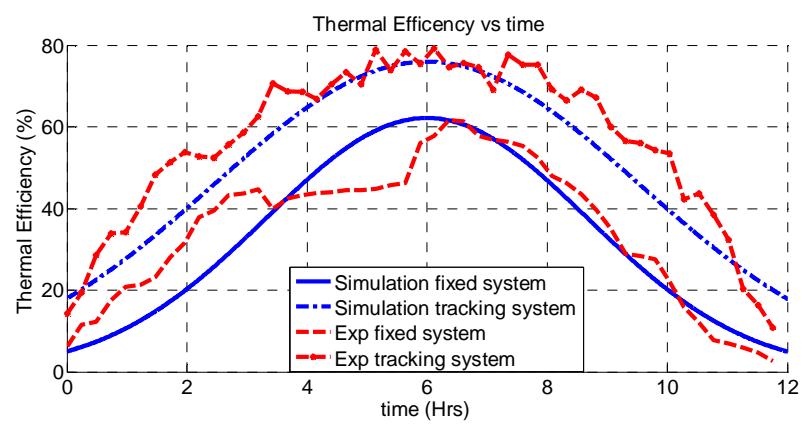

Fig 26: Comparison between the total efficiencies with 12 hour's morning for fixed and tracking PV-modules with pipes cooling on $31^{\text {st }}$ December $\& 1^{\text {st }}$ January.

\section{CONCLUSIONS}

The present work introduces a PV/Thermal hybrid system where the efficiency of the PV modules is calculated without cooling and with cooling water system in two cases with and without controlling the flow rate of water inside thermal system. The following major conclusions are derived from the discussion of the experimental results:The cooling system reduce the PV modules temperature up to 10 and $20{ }^{\circ} \mathrm{C}$ in 
without controlling but with controlling between 10 to $30^{\circ} \mathrm{Crespectively} \mathrm{for} \mathrm{fixed} \mathrm{and} \mathrm{tracking} \mathrm{systems} \mathrm{compared} \mathrm{to}$ the non-cooling module due to the back pipes cooling. The thermal power in case of controlling reached to 10 Watt but without controlling obtained to 18 Watt. This is due to the inability of water inside the copper pipes to suspense and takes the enough time to decrease the temperature of PV panels. As the modules temperature increases the output current increases through limited range In contrast, the output voltage decreases where the band gab energy for semiconductor decreases with increases the surface temperature this cause an increase in fill factor for the module with cooling rather than without cooling and without controlling for the flow rate.As The fill factor is inversely proportional to the module surface temperature.The reduce in module surface temperatures due to cooling system causing an increase in the module daily output power obtained to $10 \%$ for fixed system while in the tracking system without controlling reached to $20 \%$ respectively compared to with controlling obtained to $30 \%$ due to back cooling.

\section{REFERENCES}

[1] "Solar Thermal Energy." New and Renewable Energy Authority.5Aug.2008<http://www.nrea.gov.eg/english1 .html>.

[2] M. Bakker, H. A. Zondag, M. J. Elswijk, K. J. Strootman, M. J. M. Jong, "Performance and costs of a roof-sized PV/thermal array combined with a ground coupled heat pump", Solar Energy 78 (2005), pp. 331339.

[3] H. Chen, Saffa B. Riffat, Yu Fu, "Experimental study on a hybrid photovoltaic/heat pump system, Applied Thermal Engineering" 31 (2011), pp. 4132-4138.

[4] H. G. Teo, P. S. Lee, and M. N. A. Hawlader, An active cooling system forphotovoltaic modules, Applied Energy 90 (2012) 309-315.

[5] D. J. Yang, Z. F. Yuan, P. H. Lee, and H. M. Yin, "Simulation and experimental validation of heat transfer in a novel hybrid solar panel", International Journal of Heat and Mass Transfer 55 (2012), pp. 10761082.

[6] The Department of Energy DOE, "FUNDAMENTALS HANDBOOK - THERMODYNAMICS, HEAT TRANSFER, AND FLUID FLOW" - Volume 2 of 3", Washington, United State of America, June (1992), pp. 11-25.

[7] Reference solar spectral irradiance: Air mass 1.5, National Renewable Energy Lab. http://rredc.nrel.gov/solar/spectra/am1.5/. Accessed 29 March 2011.

[8] Antonio Luque, Steven Hegedus, "Handbook of Photovoltaic and Engineering", Wiley (2003), pp 6287.

[9] O. Lipscombe, "MultiphysicsModeling of Sensors and Actuators", Dover Publications, New York, NY, (2013), pp. 34-81.
[10] Comsol, Version 4.2, http://www.comsol.com.

[11] A.D. Jones and C.P. Underwood, "A Thermal Model for Photovoltaic Systems", Solar Energy 70 (2001), pp. 349-359.

[12] Tony Kerzmann and Laura Schaefer, "System simulation of a linear concentrating photovoltaic system with an active cooling system", Renewable Energy 41 (2012), pp. 254-261.

[13] A. Beckman, A. William, "Solar Engineering of Thermal Processes", Wiley 4ed, pp. 13-20, (2013).

[14] M.Abderahman, A.Eliwa and Osama.Abdellatif," Effect of Aerodynamics Characteristics on Solar Cells", Cairo, Egypt , July (2012),pp.21-30.

[15] K. Åström, C. Hang, P. PerssonandW. Ho, "Towards intelligent PID control", ResearchTrianglePark, North Carolina, USA, (1992).

\section{BIOGRAPHIES}

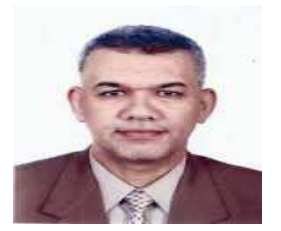

Magdy M. Abdelhameed: received his B.S.c., M.S.c. and PhD degrees from Ain Shams University, faculty of Engineering, MechanicalEngineering Department in 1983, 1989 and 1994 respectively. Currently $\mathrm{He}$ is enrolled as a head of the mechatronicsDepartment atAinShams University, faculty of Engineering. His research interests lie in the field of renewable energy especially PVs

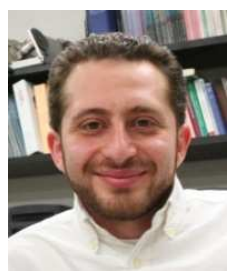

Mohamed A. Abdelaziz: received his B.S.c., degrees from Ain Shams University, faculty of Engineering, Mechanical Engineering department in 2001. He then received his M.S.c and $\mathrm{PhD}$. degrees from University of Illinois . Chicago, USA, faculty of Engineering, Mechanical Engineering Department in 2007. Currently He is enrolled as an associate professor in the Automotive Engineering Department atAin Shams University, faculty of Engineering.His research interests lie in the field of automotive systems.

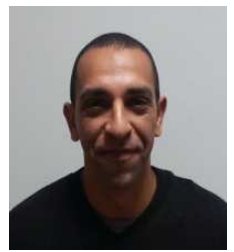

Abdelaziz B. Hussien :received the B.Sc. degree in Mechatronics Engineering, Mechanical Department from The Higher Technological Institute, Tenth of Ramadan City, Egypt, in 2007 and the M.Sc. student in Mechatronics Engineering Department at Ain Shams University, Cairo, Egypt. Currently $\mathrm{He}$ is enrolled as an demonstrator in the Mechanical Engineering Department in the British University in Egypt (BUE) His research interests lie in the field of renewable energy especially PVs. 